\title{
Serologic evidence of the recent circulation of Saint Louis encephalitis virus and high prevalence of equine encephalitis viruses in horses in the Nhecolândia sub-region in South Pantanal, Central-West Brazil
}

\author{
Alex Pauvolid-Corrêa ${ }^{1 /+}$, Fernando Neto Tavares ${ }^{1}$, Eliane Veiga da Costa ${ }^{1}$, \\ Fernanda Marcicano Burlandy ${ }^{1}$, Michele Murta', Aiesca Oliveira Pellegrin², \\ Márcia Furlan Nogueira' ${ }^{2}$, Edson Elias da Silva ${ }^{1}$
}

'Laboratório de Enterovírus, Instituto Oswaldo Cruz-Fiocruz, Ministério da Saúde, Av. Brasil 4365, 21045-900 Rio de Janeiro, RJ, Brasil ${ }^{2}$ Embrapa Pantanal, Ministério da Agricultura Pecuária e Abastecimento, Corumbá, MS, Brasil

As in humans, sub-clinical infection by arboviruses in domestic animals is common; however, its detection only occurs during epizootics and the silent circulation of some arboviruses may remain undetected. The objective of the present paper was to assess the current circulation of arboviruses in the Nhecolândia sub-region of South Pantanal, Brazil. Sera from a total of 135 horses, of which 75 were immunized with bivalent vaccine composed of inactive Eastern equine encephalitis virus (EEEV) and Western equine encephalitis virus (WEEV) and 60 were unvaccinated, were submitted to thorough viral isolation, reverse transcriptase polymerase chain reaction (RT-PCR) and neutralization tests for Saint Louis encephalitis virus (SLEV), EEEV, WEEV and Mayaro virus (MAYV). No virus was isolated and viral nucleic-acid detection by RT-PCR was also negative. Nevertheless, the prevalence of neutralizing antibodies in horses older than seven months was $43.7 \%$ for SLEV in equines regardless of vaccine status, and $36.4 \%$ for WEEV and $47.7 \%$ for EEEV in unvaccinated horses. There was no evidence of MAYV infections. The serologic evidence of circulation of arboviruses responsible for equine and human encephalitis, without recent official reports of clinical infections in the area, suggests that the Nhecolândia sub-region in South Pantanal is an important area for detection of silent activity of arboviruses in Brazil.

Key words: arbovirus - Pantanal - RT-PCR - neutralization - equines - Brazil

The arboviruses are maintained in nature due to the biological transmission of an infected vertebrate host to another through hematophagous arthropods and, with few exceptions, are etiological agents of zoonoses that depend on animal species other than humans for maintenance in nature (WHO 1985). Humans and horses generally are terminal or incidental hosts that usually do not contribute to the transmission cycle by developing viraemia and infecting arthropods (Gubler 2002).

Wetland ecosystems like the Brazilian Pantanal, which have high movement of migratory birds (Nunes \& Tomas 2004), diversity of arbovirus vectors (Pauvolid-Corrêa et al. 2010) and arbovirus circulation (Iversson et al. 1993), present favorable conditions for reservoirs, which can sustain arbovirus circulation in imperceptible enzootic cycles (Pauvolid-Corrêa \& Varella 2008).

Financial support: CNPq, FIOCRUZ

$\mathrm{APC}$ is a recipient of the scholarship of CNPq in the Doctor of Tropical Medicine Program at the Fiocruz.

This work is part of APC's MSc Thesis, defended at the Instituto Oswaldo Cruz-Fiocruz, Ministério da Saúde, Rio de Janeiro, Brazil, in 2008. Presented in part at the XIX National Meeting of Virology, Caxambú, MG, November 16-19th, 2008.

+ Corresponding author: pauvolid@ioc.fiocruz.br

Present address: Laboratório de Flavivírus, IOC-Fiocruz

Received 14 December 2009

Accepted 5 July 2010
Encompassing approximately $140.000 \mathrm{~km}^{2}$ across the territories of Brazil, Bolivia and Paraguay, Pantanal is one of the world's largest freshwater wetland ecosystem and the most significant South American waterbird breeding area (Lopes et al. 2006). In Brazil, where $85 \%$ of the total area is located, $65.5 \%$ is situated in the state of Mato Grosso do Sul (MS), known as South Pantanal (Alho et al. 1988, Moraes et al. 2001). The region is ecologically classified into sub-regions that differ in degree of vegetation, flooding and physiognomy (Adámoli 1987). The Nhecolândia sub-region located in South Pantanal occupies $19.48 \%$ of the total area and is one of the largest of the floodplain (Silva \& Abdon 1998). The main economic activity of the region is beef cattle breeding characterized by vast areas of native grassland and low human population density with little impact on the Pantanal environment (Junk \& Cunha 2005).

In the 1990s, a serologic survey for antibodies to arboviruses in equine sera was conducted in South Pantanal and detected the circulation of some arboviruses, including equine encephalitis viruses (Iversson et al. 1993). Since then, some properties have conducted a vaccination program to prevent viral equine encephalitis (Santos et al. 2005).

Nevertheless, there is no recent data concerning local arbovirus circulation in the area and the main objective of the present study was to conduct a virologic and serologic survey for antibodies to Saint Louis encephalitis virus (SLEV), Western equine encephalitis virus (WEEV), Eastern equine encephalitis virus (EEEV) and Mayaro virus (MAYV) as well as a molecular investigation for the presence of alphaviruses and flaviviruses to update 
our knowledge of arbovirus circulation in equines from the Nhecolândia sub-region of South Pantanal.

The field stations used in this study were two local ranches comprising a total area of 30.000 ha or $300 \mathrm{~km}^{2}$. Ranch A (RA), a research station on federal property of approximately 4.500 ha and Ranch B (RB), a privately owned beef cattle ranch within approximately $25.500 \mathrm{ha}$, are both located in the Nhecolândia sub-region $\left(18^{\circ} 20^{\prime}-\right.$ $19^{\circ} 40^{\prime} \mathrm{S}$ and $57^{\circ} 54^{\prime}-55^{\circ} 00^{\prime} \mathrm{W}$ ) approximately $150 \mathrm{~km}$ east of Corumbá, MS.

In February of 2007 during the rainy season, serum samples were obtained from 135 equines, 93 from RA and 42 from RB. From 93 equines sampled at RA, 75 were immunized on May 2006 with a bivalent vaccine composed of inactive EEEV and WEEV as part of an annual vaccination program for equine encephalitis prevention. None of the 42 horses from RB was vaccinated as the vaccination program was not conducted on this property. All 60 unvaccinated horses from the two properties had no records of travel outside South Pantanal. The mean age of RA horses was 5.9 years (range, 20 days-20 years). All horses from RA had a known date of birth, whereas the animals of RB, mostly untamed, had no records available. Thirty-four horses were intact males, 43 were geldings and 58 were females. All animals from RA were thoroughbreds of the Cavalo Pantaneiro breed and the entire flock of RB was crossbred. All 135 samples were submitted to viral isolation, reverse transcriptase polymerase chain reaction (RT-PCR) and neutralization tests (NT).

Aliquots of $200 \mu \mathrm{L}$ of 1:10 dilution from equine sera were inoculated into Vero cell monolayer tubes $\left(5 \times 10^{5}\right.$ cells $/ \mathrm{mL}$ ). Briefly, the tubes were kept at $36^{\circ} \mathrm{C}$ for $1 \mathrm{~h}$ with discrete motion every $15 \mathrm{~min}$ to optimize virus adsorption. At the end of this period, $1.800 \mu \mathrm{L}$ of medium 199 containing $2 \%$ of bovine fetal serum was added followed by incubation for seven days. Tubes were daily observed under an inverted microscope for evidence of cytopathic effects (CPE). Three consecutive passages of seven days each, for a total of 21 days, were performed. The absence of CPE after three consecutive inoculations was considered absence of cytopathogenic viruses in a given sample.

All samples were submitted to RNA extraction using a commercial kit (QIAamp ${ }^{\circ}$ Viral RNA Mini Kit QIAGEN) in accordance with the manufacturer instructions. Reverse transcription was conducted on extracted RNA with Superscript II (Invitrogen) system and random primers (Promega).

Aliquots of $10 \mu \mathrm{L}$ of cDNA served as templates in subsequent Duplex PCR followed by Semi-Nested PCR assay for the alphaviruses Venezuelan equine encephalitis virus (VEEV), WEEV and MAYV and for the flaviviruses Ilheus virus (ILHV), Rocio virus, Yellow fever virus and SLEV detection, as previously described (de Morais Bronzoni et al. 2005).

Five microliter aliquots of cDNA of each sample were also subjected to nested PCR for the flaviviruses Japanese encephalitis virus (JEV), Dengue virus and West Nile virus (WNV) genomes detection, as previously described (Pauvolid-Corrêa et al. 2010).

All antigens used for NT were previously submitted to partial nucleotide sequencing of NS5 gene of SLEV and NS1 gene of alphaviruses. High identity scores were obtained with the following sequences deposited at Genebank: SLEV (access EU099354.1), MAYV (access DQ001069.1), WEEV (access AF214040.1) and EEEV (access X63135.1).

After heat inactivation at $56^{\circ} \mathrm{C}$ for $30 \mathrm{~min}$, sera were two-fold serially diluted in medium 199 containing $2 \%$ bovine fetal serum on 96-well plates. Dilutions were mixed with equal amounts of viral suspensions at 100 $\mathrm{CCID}_{50}$ of SLEV, MAYV, WEEV and EEEV and incubated for $1 \mathrm{~h}$ at $36^{\circ} \mathrm{C}$. After incubation, the Vero cell suspension $\left(100 \mu \mathrm{L}\right.$ of $2.5 \times 10^{5}$ cells $\left./ \mathrm{mL}\right)$ was added to each well and the plates were covered with plastic film. The plates were incubated at $36^{\circ} \mathrm{C}$ and daily observed under an inverted microscope for 5-10 days. End-point titres were determined as the higher serum dilution with total inhibition of CPE in the cell monolayer induced by $100 \mathrm{CCID}_{50}$ of the viral suspensions, as previously described (Lennette 1995). NT was performed initially at a dilution of 1:8 for screening and the reactive samples were further tested at higher dilutions (1:8-1:1024) to determine the endpoint titres. Samples were considered positive when a serum dilution of at least 1:8 was able to neutralize totally $100 \mathrm{CCID}_{50}$ of the viral suspensions.

No CPE was observed in Vero cells after three consecutive passages and viral nucleic-acid detection using different PCR-based conditions were also negative. The arbovirus infections, with some exceptions as VEEV, are characterized by low viraemia in equines, which are terminal hosts in most arbovirus cycles (Radostits et al. 2002). Virus detection in blood would require venopuncture during acute infection, a condition that may be difficult to detect in extensive breeding systems. For this study, the sera were collected from animals in the absence of clinical signs, which may have influenced and possibly explain the negative results for viral isolation and nucleic-acid detection. From a total of 135 horses, 75 had been vaccinated with EEEV/WEEV bivalent inactive vaccine. Of these, 34 (45.3\%) were seropositive for SLEV, 67 (89.3\%) for EEEV and 44 (58.6\%) for WEEV (Fig. 1). Out of 60 unvaccinated horses, $24(40 \%)$ were positive for SLEV, 34 (56.6\%) for EEEV and 25 (41.7\%) for WEEV (Fig. 2).

However, to confirm EEEV and WEEV circulation, we studied unvaccinated horses that were older than seven months, as there would be no possible passive immune response. Of 60 unvaccinated horses, 44 met these criteria, and neutralizing antibodies for EEEV were detected in $21(47.7 \%)$ and for WEEV in $16(36.4 \%)$. Out of 135 horses assayed for SLEV, 119 horses were older than seven months regardless of vaccination; neutralizing anti-SLEV antibodies were detected in $52(43.7 \%)$. The positive titres ranged from 1:8-1:256 for SLEV, from 1:8- $\geq 1: 1024$ for EEEV and from 1:8-1:128 for WEEV. Four samples of unvaccinated animals show titres to SLEV, EEEV and WEEV and eight samples showed titres to EEEV and WEEV simultaneously. All samples had neutralizing antibody titres $<1: 8$ to MAYV and were considered negative for this Alphavirus species.

The positivity of $36.4 \%$ for WEEV differed from the results of similar serologic studies conducted in Brazil. 


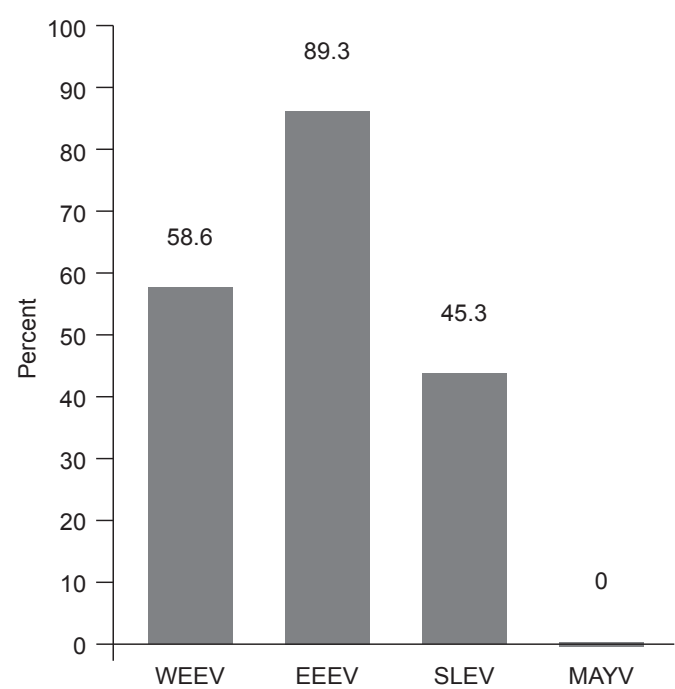

Fig. 1: prevalence by neutralization tests of 75 horses vaccinated with Eastern equine encephalitis virus (EEEV)/Western equine encephalitis virus (WEEV) inactivated vaccine. MAYV: Mayaro virus; SLEV: Saint Louis encephalitis virus.

The first evidence of WEEV circulation in the country was obtained by Bruno-Lobo et al. (1961) in the city of Rio de Janeiro through an equine serologic investigation where $22.2 \%$ of the animals evaluated were positive. A serologic survey carried out in horse sera collected at the same region of our studied area showed only $2 \%$ positivity to WEEV in the sera assayed by hemaglutination inhibition (HI) and NT (Iversson et al. 1993). The difference in seroprevalence for WEEV among the surveys conducted in the same area may suggest a relevant increase of circulation of this equine encephalitis virus member in the region. Nevertheless, other possible causes such as differences in methodology or interpretation of results must be considered.

The seroprevalence of $47.7 \%$ to EEEV is also higher than that observed in most serologic surveys carried out in South America. In the 1970s, positivity to EEEV in Argentina was detected in $11.1 \%$ of 892 equines assayed (Monath et al. 1985). In Brazil, Lennette and Fox (1943), during the first investigation of arboviral encephalitis in horses conducted in the country, found that $18.4 \%$ of equines assessed were positive for EEEV in the state of Minas Gerais. In the state of Rio de Janeiro, Travassos et al. (1961) detected antibodies to EEEV by HI in $10 \%$ of the samples assessed. In the previously cited serologic survey conducted in the same region in the 1990 s, seropositivity to EEEV was $6.7 \%$ of 432 animals assayed (Iversson et al. 1993). On the other hand, our results were similar to a recent investigation carried out by Fernández et al. (2000) after epizootic encephalitis in the state of Paraná (PR) in which $54.5 \%$ of the horses assayed had anti-EEEV antibodies by HI. Unfortunately, we could not clarify the timing of the circulation of equine encephalitis viruses, since the date of birth of nonvaccinated animals was unavailable.

The detection in this study of a high seropositivity to WEEV and EEEV was associated with a previous report of

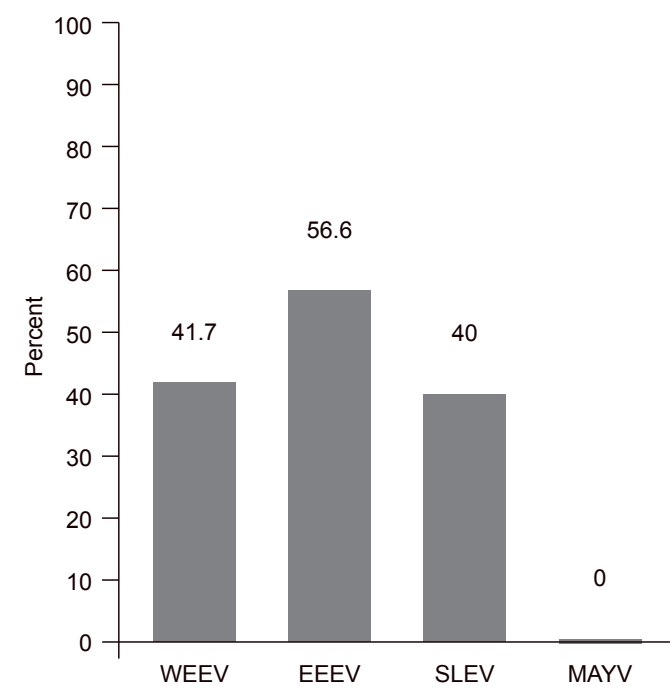

Fig. 2: prevalence by neutralization tests of 60 horses unvaccinated with Eastern equine encephalitis virus (EEEV)/Western equine encephalitis virus (WEEV) inactivated vaccine. MAYV: Mayaro virus; SLEV: Saint Louis encephalitis virus.

a clinical infection of EEEV in MS in the 1990s and more recently in PR, a neighboring state. This finding reinforces the need for implementation of local surveillance of equine encephalitis viruses. The circulation of MAYV or even its potential vectors in South Pantanal are unknown. Because no positive results for MAYV antibodies were detected in all equines assessed, the following assumptions must be considered: the absence of MAYV circulation in the area; the biological characteristics of potentials local vectors, as the non use of horses as a food source and finally, there are no MAYV vectors in the area.

Despite Haemagogous spp, the main known vectors of MAYV (Causey 1962), display an acrodendrophilic characteristic of preferring the canopy in the forest, this species can fly over large areas and descend to bite animals (de Thoisy et al. 2004) and humans mainly in disturbed forests and when they reach high population density (Consoli \& Lourenço-de-Oliveira 1994). Because its biological plasticity, the hematofagia on horses by this acrodendrophilic species was considered and MAYV investigation in horses was conducted. However, in a recent preliminary investigation conducted in the same sub-region of our study, of a total of 22 Culicidae species identified, the Haemagogous spp were not captured (Pauvolid-Corrêa et al. 2010).

However, many more entomological studies are needed, because these vectors are intensely active during the daytime, a feature little explored in the only Culicidae species study conducted in the area. Despite our negative results, the serologic evidence of MAYV infection in Indians (Neel et al. 1968) and an outbreak registered (Vasconcelos et al. 1998) in the two neighboring states associated with the report of three cases of MAYV fever in men infected in MS (Coimbra et al. 2007) are evidence of MAYV circulation in the Central-West region of Brazil. Moreover, MAYV was detected in migratory birds in the state of Rio Grande do Sul (MS 2003) and six of these avian species 
were already observed in South Pantanal (Nunes \& Tomas 2004). These data are particularly important because, although vertebrate hosts of MAYV are nonhuman primates, birds that can cover large distances in a short time can act as secondary hosts carrying MAYV in the viraemia phase (Vasconcelos et al. 1998). The absence of seropositivity for MAYV in all samples suggests a lack of cross reaction between the alphaviruses assayed.

Regarding the NT results for SLEV, this is the first serologic evidence of SLEV circulation in South Pantanal. The detection of SLEV antibodies in $43.7 \%$ of animals older than seven months was relatively similar to the result described in another serologic survey carried out in Argentina, where the positivity to SLEV was detected by Monath et al. (1985) in 57.9\% of equines studied. In Brazil, our results were also similar to a recent report of an equine serosurvey conducted in 2005 in the Amazon region and Maracajú, a municipality of MS outside South Pantanal. In this inquiry, neutralizing antibodies to a chimeric SLEV were detected in $50.9 \%$ of 1,401 animals assessed (Rodrigues et al. 2010). Despite the similarity of these results, it is important to consider the different criteria used for serologic diagnosis. Considering the vast co-circulation of flaviviruses in Brazil and consequently its cross-reactivity, our positive samples that neutralized $100 \%$ of $100 \mathrm{CCID}_{50}$ of sylvatic SLEV aimed to restrict but not completely prevent cross-reactions.

Although NT is the most specific serologic assay for Flavivirus diagnosis, the previous report of ILHV circulation (Iversson et al. 1993) and the peculiar ecologic conditions of the South Pantanal that are propitious to arbovirus circulation suggest that another Flavivirus species must be considered in future serosurveys.

Neutralizing antibodies to SLEV in animals aged 3-21 years without history of travel outside of Pantanal suggests that SLEV circulated between 2004-2007. This data could be particularly interesting as the human outbreak of SLEV occurred in 2005 in Córdoba province, Argentina (Spinsanti et al. 2008). Recent SLEV circulation has also been reported in Brazil in birds, human and nonhuman primates on different regions of the country (Rocco et al. 2005, Santos et al. 2006, Mondini et al. 2007, Cruz et al. 2009, Nunes et al. 2009). The seropositivity for SLEV in five animals with history of travel to Poconé, a municipality of Mato Grosso (MT), indicates possible infection outside of MS, which should be taken into account by arbovirus surveillance in MT.

Regarding the 75 equines with vaccination history, Waldridge et al. (2003) studied the immune response of equines to the equine encephalitis virus vaccine and revealed that some animals had lower levels of WEEV antibody and, in some cases, total depletion of the antibodies was observed seven months after vaccination. Their result is in agreement with our study where $31(41.4 \%)$ of 75 animals vaccinated in May 2006 did not show neutralizing antibodies to WEEV at the time of venopuncture, which occurred nine months after vaccination.

The high prevalence of EEEV and WEEV was associated with nonofficial reports of horses with clinical signs typical of neurologic diseases and reinforces the need for the maintenance of the viral encephalitis vaccination program, which is already carried out by some properties, as well as its implementation, mainly for EEEV, by other properties located in the Nhecolândia sub-region.

Despite unapparent SLEV infection in horses and the high specificity of NT, it is important to consider that the close genetic relationship among other species of the JEV group could foil the recognition of previously undetected related species of the group, which occurred in New York City (USA) in the 1990s during the introduction of WNV (CDC 1999).

In Pantanal, the extensive cattle system favors a close contact of the livestock as well as the equines with the local sylvatic fauna and vector populations. Therefore, the horses of Pantanal should be considered as important markers for arbovirus circulation in the area.

In this peculiar cattle livestock, the veterinary assistance is often scarce and most horse deaths are visually attributed by the rural workers to snake bite or equine infectious anemia (EIA), a horse infectious disease wellknown by locals. In fact, EIA is highly prevalent in the horses of Pantanal (Silva et al. 2001) and its economic importance may direct the eventual laboratory diagnosis of this Lentivirus infection, which could to foil the circulation of other important etiological agents, including those previously not detected in Brazil.

\section{ACKNOWLEDGEMENTS}

To Drs Davis Fernandes Ferreira (UFRJ), Maulori Curié Cabral (UFRJ) and Filipe Anibal Castro (Fiocruz), for your contribution, to the rural workers of Pantanal ranches, Gonçalo and family, Márcio da Silva, Roberto Rondon, Vitor Gonzales and Vandir da Silva, and to the local ranch owners, for your collaboration.

\section{REFERENCES}

Adámoli J 1987. Fisiografia do Pantanal. In AC Allem, JFM Valls, Recursos forrageiros nativos do Pantanal Mato-Grossense, Embrapa Cenargen, Documento 8, Brasília, p. 15-22.

Alho CJR, Lacher TE, Conçales HC 1988. Environmental degradation in the Pantanal ecosystem. Bioscience 38: 164-171.

Bruno-Lobo GG, Bruno-Lobo M, Travassos J, Pinheiro F, Pazin IP 1961. Estudos sobre arbovírus III. Isolamento de um vírus sorologicamente relacionado ao sub-grupo Western-Sindbis de um caso de encefalomielite eqüina ocorrido no Rio de Janeiro. An Microbiol 9: 183-195.

Causey OR 1962. The isolation of virus from natural and sentinel hosts in the Amazon valley. Revista do Serviço Especial de Saúde Pública 12: 25-31.

CDC - Centers for Disease Control and Prevention 1999. Outbreak of West Nile-like viral encephalitis-New York, 1999. MMWR Morb Mortal Wkly Rep 48: 845-849.

Coimbra TL, Santos CL, Suzuki A, Petrella SM, Bisordi I, Nagamori AH, Marti AT, Santos RN, Fialho DM, Lavigne S, Buzzar MR, Rocco IM 2007. Mayaro virus: imported cases of human infection in São Paulo state, Brazil. Rev Inst Med Trop Sao Paulo 49: 221-224.

Consoli RAGB, Lourenço-de-Oliveira R 1994. Principais mosquitos de importância sanitária no Brasil, Editora Fiocruz, Rio de Janeiro, $228 \mathrm{pp}$.

Cruz AC, Prazeres A do S, Gama EC, Lima MF, Azevedo R do S, Casseb LM, Nunes Neto JP, Martins LC, Chiang JO, Rodrigues SG, Vasconcelos PF 2009. Vigilância sorológica para arbovírus em Juruti, Pará, Brasil. Cad Saude Publica 25: 2517-2523. 
de Morais Bronzoni RV, Baleotti FG, Ribeiro Nogueira RM, Nunes M, Moraes Figueiredo LT 2005. Duplex reverse transcription-PCR followed by nested PCR assays for detection and identification of Brazilian alphaviruses and flaviviruses. J Clin Microbiol 43: 696-702.

de Thoisy B, Gardon J, Salas RA, Morvan J, Kazanji M 2003. Mayaro virus in wild mammals, French Guiana. Emerg Infect Dis 9: 1326-1369.

Fernández Z, Richartz R, Travassos da Rosa A, Soccol VT 2000. Identificação do vírus causador da encefalomielite eqüina, Paraná, Brasil. Rev Saude Publica 34: 232-235.

Gubler DJ 2002. The global emergence/resurgence of arboviral diseases as public health problems. Arch Med Res 33: 330-342.

Iversson LB, Silva RA, da Rosa AP, Barros VL 1993. Circulation of eastern equine encephalitis, western equine encephalitis, Ilhéus, Maguari and Tacaiuma viruses in equines of the Brazilian Pantanal, South America. Rev Inst Med Trop Sao Paulo 35: 355-359.

Junk WJ, Cunha CN 2005. Pantanal: a large South American wetland at a crossroads. Ecol Eng 24: 391-401.

Lennette DA 1995. General principles for laboratory diagnosis of viral, rickettsial and chlamydial infectious. In EH Lennette, DA Lennette, ET Lennette, Diagnostic procedures for viral, rickettsial and chlamydial infectious, 7 ed., American Public Health Association, Washington DC, p. 3-26.

Lennette EH, Fox JP 1943. Anticorpos neutralizantes para a amostra leste do vírus de encefalomielite equina em equídeos no Brasil. Mem Inst Oswaldo Cruz 38: 85-92.

Lopes IF, Brito RA, Henrique-Silva F, Del Lama SN 2006. Demographic history of wood stork (Mycteria americana) Brazilian Pantanal colonies revealed by mitochondrial DNA analysis. Genet Mol Biol 29: 241-250.

Monath TP, Sabattini MS, Pauli R, Daffner JF, Mitchell CJ, Bowen GS, Cropp CB 1985. Arbovirus investigations in Argentina, 1977-1980. IV. Serologic surveys and sentinel equine program. Am J Trop Med Hyg 34: 966-975.

Mondini A, Cardeal IL, Lázaro E, Nunes SH, Moreira CC, Rahal P, Maia IL, Franco C, Góngora DV, Góngora-Rubio F, Cabrera EM, Figueiredo LT, da Fonseca FG, Bronzoni RV, Chiaravalloti-Neto F, Nogueira ML 2007. Saint Louis encephalitis virus, Brazil. Emerg Infect Dis 13: 176-178.

Moraes AS, ResendeEK, RodriguesCAG,MauroRA, GaldinoS, Oliveira MD, Crispim SMA, Vieira LM, Soriano BMA, Abreu UGP, Mourão G 2001. Embrapa Pantanal: 25 anos de pesquisas em prol da conservação do Pantanal, os desafios do novo milênio. In III Simpósio sobre recursos naturais e sócio-econômicos do Pantanal: o desafio do novo milênio, Embrapa Pantanal, Corumbá, 55 pp.

MS - Ministério da Saúde, Brasil 2003. Secretaria de Vigilância em Saúde. Primeiro inquérito sorológico em aves migratórias e nativas do Parque Nacional da Lagoa do Peixe/RS para detecção do vírus da febre do Nilo ocidental e outros vírus. Boletim Eletrônico Epidemiológico 3: 3-12.

Neel JV, Andrade AH, Brown GE, Eveland WE, Goobar J, Sodeman WA Jr, Stollerman GH, Weinstein ED, Wheeler AH 1968. Further studies of the Xavante Indians. IX. Immunologic status with respect to various diseases and organisms. Am J Trop Med Hyg 17: 486-498.

Nunes AP, Tomas WM 2004. Aves migratórias ocorrentes no Pantanal: caracterização e conservação, Embrapa Pantanal, Documento 62, Corumbá, 29 pp.

Nunes MR, Barbosa TF, Casseb LM, Nunes Neto JP, Segura N de O,
Monteiro HA, Pinto EV, Casseb SM, Chiang J de O, Martins LC, Medeiros DB, Vasconcelos PF 2009. Eco-epidemiologia dos arbovírus na área de influência da rodovia Cuiabá-Santarém (BR-163), estado do Pará, Brasil. Cad Saude Publica 25: 2583-2602.

Pauvolid-Corrêa A, Tavares FN, Alencar J, Silva J dos S, Murta M, Serra-Freire NM, Pellegrin AO, Gil-Santana H, Guimarães AE, Silva EE 2010. Preliminary investigation of Culicidae species in South Pantanal, Brazil and their potential importance in arbovirus transmission. Rev Inst Med Trop Sao Paulo 52: 17-24.

Pauvolid-Corrêa A, Varella RB 2008. Aspectos epidemiológicos da febre do oeste do Nilo. Rev Bras Epidemiol 11: 463-472.

Radostits OM, Gay CC, Blood DC, Hinchcliff KW 2002. Clínica veterinária - Um tratado de doenças dos bovinos, ovinos, suínos, caprinos e eqüinos, 9th ed., Guanabara Koogan, Rio de Janeiro, 1737 pp.

Rocco IM, Santos CL, Bisordi I, Petrella SM, Pereira LE, Souza RP, Coimbra TL, Bessa TA, Oshiro FM, Lima LB, Cerroni MP, Marti AT, Barbosa VM, Katz G, Suzuki A 2005. St. Louis encephalitis virus: first isolation from a human in Sao Paulo state, Brazil. Rev Inst Med Trop Sao Paulo 47: 281-285.

Rodrigues SG, Oliva OP, Araujo FAA, Martins LC, Chiang JO, Henriques DF, Silva EVP, Rodrigues DSG, Prazeres ASC, Tavares-Neto J, Vasconcelos PFC 2010. Epidemiology of Saint Louis encephalitis virus in the Brazilian Amazon region and in the state of Mato Grosso do Sul, Brazil: elevated prevalence of antibodies in horses. Rev Pan-Amaz Saude 1: 81-86.

Santos E, Almeida MAB, Fonseca DF, Vasconcelos PFC, Rodriguez SG 2006. Registro de anticorpos para o vírus Saint Louis em primata não humano no estado do Rio Grande do Sul. Boletim Eletrônico Epidemiológico 8: 6-7.

Santos SA, Mazza MCM, Sereno JRB, Pedreira ACMS, Mariante A da S, Comastri Filho JA, Silva JA, Marques MCA 2005. Descrição do manejo geral de cavalos pantaneiros na região do Pantanal, Embrapa Pantanal, Boletim de Pesquisa e Desenvolvimento 63, Corumbá, 20 pp.

Silva JV, Abdon MM 1998. Delimitação do Pantanal brasileiro e suas sub-regiões. Pesq Agrop Bras 33: 1703-1711.

Silva RAMS, Abreu UGP, Barros ATM 2001. Anemia infecciosa eqüina: epizootiologia, prevenção e controle no PantanaL, Embrapa Pantanal, Circular Técnica 29, Corumbá, 32 pp.

Spinsanti LI, Díaz LA, Glatstein N, Arselán S, Morales MA, Farías AA, Fabbri C, Aguilar JJ, Ré V, Frías M, Almirón WR, Hunsperger E, Siirin M, Da Rosa AT, Tesh RB, Enría D, Contigiani M 2008. Human outbreak of St. Louis encephalitis detected in Argentina, 2005. J Clin Virol 42: 27-33.

Travassos J, Bruno-Lobo M, Bruno-Lobo GG 1961. Estudos sobre arbovírus. V. Inquérito sorológico e avaliação da imunidade pósvacinal em eqüinos no Rio de Janeiro. An Microbiol 9: 213-228.

Vasconcelos PFC, Travassos da Rosa APA, Pinheiro FP, Shope RE, Degallier N, Travassos da Rosa ES 1998. Arboviruses pathogenic for man in Brasil. In APA Travassos da Rosa, PFC Vasconcelos, JFS Travassos da Rosa, An overview of arbovirology in Brazil and neighbouring countries, Instituto Evandro Chagas, Belém, p. 72-99.

Waldridge BM, Wenzel JG, Ellis AC, Rowe-Morton SE, Bridges ER, D'Andrea G, Wint R 2003. Serologic responses to eastern and western equine encephalomyelitis vaccination in previously vaccinated horses. Vet Ther 4: 242-248.

WHO - World Health Organization 1985. Virosis transmitidas por artrópodos y roedores, Genebra, Graficas Reunidas, 126 pp. 